\title{
8. West Papuan control How red tape, disinformation and bogus online media disrupts legitimate news
}

\section{sources}

\begin{abstract}
Indonesia is ranked 124th out of 180 countries in the 2019 Global Press Freedom Index. West Papua, comprising the two Melanesian provinces of Papua and West Papua, is a significant factor is this low ranking. While other parts of Indonesia enjoy relatively free media coverage, West Papua remains the most closed region to media access, particularly to foreign media. There are patterns of threats that implicate the safety and security of local journalists in the territory. A clearing house, an intricate red-tape system, was re-introduced in May 2019 to screen foreign journalists going to the region of West Papua. Journalists require a permit to go there. Security forces monitor the journalists during their work in the region. In the past decade, two journalists have been killed, multiple journalists have been assaulted and arrested, and international journalists deported. Most of the cases remain open with no clear investigation process. Online media disrupts the work of legitimate news sources, sharing positioned disinformation to manipulate the public. There is no freedom of expression or freedom of information in West Papua.
\end{abstract}

Keywords: censorship, democracy, freedom of expression, harassment, human rights, immigration, Indonesia, journalism, media freedom, West Papua

\section{PELAGIO DA COSTA SARMENTO \\ Researcher, TAPOL, London \\ VICTOR MAMBOR \\ Editor-in-chief, Tabloid Jubi, Jayapura}

\footnotetext{
IVIL RESISTANCE movements have gained traction organising protests against human rights violations in West Papua and demanding the right to self-determination. Consequently, the Indonesian government has tightened security control over West Papua by maintaining the presence of both military and police force. These state security forces have been deployed to stop rallies or discussions on human rights and/or political issues, and clamp down on the freedom of expression, association and assembly. Human rights violations and extrajudicial killings by the military and police in West Papua
} 
rarely make the headlines in the mainstream media.

In February 2006, the Indonesian Defence Minister, Juwono Sudarsono, was quoted over the deportation of five Australian journalists after being arrested in West Papua, saying: 'We believe that Indonesian unity and cohesion would be threatened by an intrusion and a foreign interest' (Five Australian journalists expelled, 2006). In May 2015, President Joko Widodo promised to open up access to West Papua for foreign media. (Setiawan, 2015). However this promise has yet to be fulfilled. There have been many cases since then where access to foreign media has been limited or refused. Further, there are several cases of foreigners visiting West Papua being deported from Indonesia on suspicion of being journalists.

In May 2019, the head of the immigration division in the regional office of the Ministry for Law and Human Rights in Papua Province reaffirmed a 'clearing house' system for any foreign journalists wanting to visit West Papua (Government keeps restrictive policy, 2019). If a permit is granted, the foreign journalist will then be supervised by the security forces during their entire working trip in West Papua. Indonesia is ranked 124th out of 180 countries in the 2019 Global Press Freedom Index. The region of West Papua is a significant factor in this low ranking. While other parts of Indonesia enjoy relatively free media coverage, West Papua remains the most closed region to media access, particularly to foreign media. There are patterns of threats that implicate the safety and security of local journalists in the territory. In the past decade, two journalists have been killed, multiple journalists have been assaulted and arrested, and international journalists deported. Most of the cases remain open with no clear investigation process. Online media disrupts the work of legitimate news sources, sharing positioned disinformation to manipulate the public. There is no freedom of expression or freedom of information in West Papua.

Key media and organisations have attempted to address this imbalance. TAPOL is a London-based human rights organisation established in 1973 that campaigns for human rights, peace and democracy in Indonesia. TAPOL has been a consistent voice campaigning for freedom of expression and freedom of assembly in the region of West Papua. Jubi was founded in 2001, a registered independent West Papua-based media producing printed daily news and an online portal. Jubi provides training for West Papuan journalists and actively advocates for freedom of expression and freedom of the press in West Papua.

West Papuans have been experiencing serious human rights violations, including torture, imprisonment and extrajudicial killings by the Indonesian security forces, both police and military (Sara, Worthington \& Mambor, 2020). The West Papuans have long expressed their desire for self-determination since Indonesia took over the territory from Dutch colonial rule in 1963. It was officially incorporated into the Indonesian state in 1969 after an 'Act of Free Choice', a 
controversial plebiscite organised by the United Nations while only permitting the participation of 1,025 men and women (Act of Free Choice, n.d.). Simmering low level conflict between various pro-independence groups and the Indonesian army has been ongoing since then, with the continued existence of local armed groups in West Papua.

The following sections of this article discuss evidence gathered from the direct experience of Jubi reporters as well information that TAPOL has received directly on the ground. For the purpose of this submission, we have cross-referenced with media monitoring organisations such as Reporters Sans Frontières (RSF) and Human Rights Watch (HRW).

\section{Evidence gathered by Jubi and TAPOL}

Journalists in West Papua have faced serious threats in the last 10 years, and continue to do so, not only in getting access to information but also in terms of their own personal safety. These are some of the reported cases that reflect this situation:

Cases related to local journalists:

Mysterious circumstances surround the death in 2010 of journalist Ardiansyah Matrais, a correspondent for Jubi and Merauke TV. He was reported missing on 28 July 2010. On July 30, his body was retrieved from the Gudang Arang Merauke river. According to the autopsy report by the police, Ardiansyah was still alive when he was thrown into the river. The Papuan Independent Journalists Alliance (AJI Papua) suspected that Ardiansyah was tortured and killed by unknown assailants and demanded that the police in Merauke conduct a thorough investigation and bring the perpetrators to justice. However, there was never any significant effort made to investigate Ardiansyah's case.

AJI suspected that Ardiansyah's killing had to do with a series of threats against journalists in the days leading up to local elections in Merauke (AJI Jayapura, 2010; Journalist's death, 2010). In August 2010, AJI conducted its own investigation. The result showed that there were indications of torture on the victim's body. They discovered traces of strangulation on his neck, his ears had been bleeding and there were bruises over his body, indicating that he had been beaten using blunt objects. His case remains unresolved.

The Jakarta Globe daily and Vivanews.com correspondent Banjir Ambarita was stabbed while driving a motorbike in 2011. It is suspected that the motive was related to an article he had written on the sexual abuse of a detainee by three police officers (Papua-based reporter seriously injured, 2011). No further investigation was taken over his case.

Leiron Kogoya was a journalist for Pasific Post and Papua Pos Nabire. He died in 2012 when his plane was shot down by gunmen at an airport in Papua 
province. Although he was not specifically the target, his death served as a reminder of the dangers that journalists face in West Papua (Journalist killed as gunmen attack plane, 2012).

Abeth You is a journalist writing for Jubi. He was attacked by police in October 2015. At the time he was covering a demonstration on human rights violations in West Papua (RSF tells Indonesia to stop flouting journalists' rights, 2016).

Ardi Bayage reports for Suarapapua.com. He was arrested in 2016 when covering a protest during World Press Freedom Day. Bayage showed his press card to the police, but his credentials were rejected and he was accused of lying. He was held for several hours in police headquarters in Jayapura Papua (RSF tells Indonesia to stop flouting journalists' rights, 2016).

In May 2018, the Jubi journalist Abeth You filmed the police beating his colleague Mando Mote on his mobile phone. He was choked by a member of the police, his mobile phone was taken away and his press card was destroyed. The two journalists were attending a public debate involving local candidates in Deiyai, prior to the local election in 2018 (Polda Papua haras pecat, 2018).

Cases related to foreign journalists:

In September 2006, five Australian Channel Seven journalists were detained and put under surveillance in Jayapura, Papua province. Naomi Robson, Rohan Travis, Peter Andrew, Paul Richard and David John were detained on charges of entering the province with tourist visas. They were forced onto a flight back to Jakarta on September 14 from where they were expelled from the country. Papua police chief Major-General Tommy Jacobus told AP, 'They admitted being journalists trying to report on the situation here. It is best that we deport them'. Indonesian Defence Minister Juwono Sudarsono said in February 2006: 'We believe that Indonesian unity and cohesion would be threatened by an intrusion and a foreign interest' (Five Australian journalists expelled, 2006).

Two French journalists, Thomas Dandois and Valentine Bourrat, were detained in Papua province in August 2014. They were producing coverage about West Papua for the Franco-German TV channel Arte. They were charged with violation of immigration regulations and promoting instability. Their local guide and interpreter was also arrested and interrogated by the police for 36 hours (Two French journalists held for past five days, 2014).

On 8 January 2016, the Indonesian Embassy in Bangkok informed journalist Cyril Payen that his application for a visa to visit Indonesia and carry out reporting in Papua province had been denied. The Indonesian Ministry of Foreign Affairs officials later informed the French Embassy in Jakarta that the denial of the visa to journalist Cyril Payen was because his previous reporting on the pro-independence movement was 'biased and unbalanced' (Kine, 2016). 
French journalist Basil Longchamp and his camera crew were granted permission to work on a documentary in Indonesia covering West Papua in 2017. On arrival in Indonesia, they were expelled and banned from returning. The authorities accused them of showing 'lack of coordination with relevant institutions' (RSF asks Indonesia's president to let journalists work, 2017).

The Australian BBC journalist Rebecca Henschke and her crew received an official permit to cover a military aid operation in West Papua in 2018. However, when the authorities found out about her Twitter post showing troops providing only non-nutritious foodstuffs, the journalist and her crew were expelled on the grounds that her post 'hurt the feelings' of the soldiers (RSF's [sic] decries journalist's expulsion, 2018).

Doctoral candidate in Indonesian studies at Macquarie University in Australia Belinda Lopez was detained in Denpasar after arriving from Bali for her honeymoon in 2018. She was also planning to visit West Papua to attend a festival. Immigration officials told her that her name was blacklisted without offering any other justification or explanation about why. Belinda Lopez formerly worked as a reporter in Jakarta. She had already been deported from West Papua once in 2016 on suspicion of being a journalist (Australian student barred, 2018; Kine, 2018).

The above examples exemplify acute risks and barriers for journalists working in West Papua. Additionally, foreigners who enter West Papua face the potential threat of being accused of carrying out journalism activities in West Papua. In 2018, Jakub Skrzypski, a Polish citizen was arrested initially on suspicion of carrying out journalistic activities (Indonesia jails Polish tourist, 2019). He is currently in jail in West Papua convicted of treason due to attending a meeting with National Committee for West Papua (KNPB) members. Also in December 2018, an Australian citizen, Ronda Amy Harman was arrested in Surabaya. She was suspected of being a journalist, trying to cover a protest during which there were mass arrests of students (Tehusijarana \& Boediwardhana, 2018).

\section{The spread of bogus online media platforms}

West Papua also suffers from the existence of bogus online media. According to an investigation by Jubi and a Jakarta-based news website, Tirto, in 2018 there were around 18 online media platforms publishing hoaxes and propaganda regarding West Papua. This included quoting fictitious sources and conveying strong bias in favour of the police and the military in West Papua (Media siluman di Papua, 2018). Their work severely disrupts the work of genuine media organisations which also have an online presence. They make a major contribution to the spread of disinformation to the public regarding the issues in West Papua. They also affect the work of civil society organisations that have limited access to the region, and that rely on the online news reporting from West Papua. 
This disinformation disrupted humanitarian work. Presently civil society has been facing difficulties in verifying information and human rights violations allegations taking place in Nduga regency, in the Central Highlands of West Papua. Indonesian police and military have been conducting a joint operation against the West Papua Liberation Army since December 2018. Independent sources have been very difficult to reach and the military has been the sole source of information. Any accounts differing from the military are declared as a hoax, whereas not a single press worker can access Nduga due to the lockdown. A local Papuan senator was reported to police when he stated that there were civilian deaths resulting from the operation. This makes balanced and accurate reporting from the ground impossible. It is also undermining the image of a free and fair media in Indonesia - one of the largest democratic nations in the world. There is very limited accountability on the part of the authorities towards the ongoing human rights crisis in West Papua.

\section{International community's responses}

The Universal Periodic Review is an opportunity for a member state of the United Nations to receive inputs and recommendations from other member states with regard to their human rights record. In relation to freedom of the press, in the past three cycles of Review (2008, 2012 and 2017) Indonesia has received seven recommendations from five member states. In particular, New Zealand (2017) and France $(2012,2017)$ called for Indonesia to respect press freedom and open access to national and international journalists to West Papua.

This development combined with the above examples show a critical pattern for media freedom in West Papua. Serious actions are necessary, particularly when viewed through a human rights lens. Indonesia is a signatory to the UN International Convention on Civil and Political Rights, which guarantees, among others, rights to freedom of expression, association, and peaceful assembly. Indonesia, as a democratic nation, needs to improve media freedom in all of the regions including West Papua. International relations can help improve Indonesian government policies particularly on this issue. For more than 70 years now, the United Kingdom has been developing strong relations with Indonesia. Therefore we recommend the following actions for the United Kingdom government to take in order to improve media freedom in Indonesia, particularly in West Papua.

\section{Recommendations for action}

Britain has taken a prominent position in promoting global media freedom as is evident from this inquiry. We therefore call on the United Kingdom to ensure freedom of the press is upheld universally, including in West Papua.

Indonesia is currently holding the rotating presidency of the UN Security Council, of which the United Kingdom is a permanent member. We call on the United Kingdom to remind Indonesia to maintain its credibility by providing 
access to the national and international media so that they can provide unrestricted coverage in West Papua.

The effort to address the proliferation of fake news and so-called post-truth politics requires open and equal access to verified information. The United Kingdom should press Indonesia to protect journalists working in West Papua and ensure that they are free from any harassment by security forces.

We also call on the United Kingdom to request that Indonesia brings to justice those responsible for attacks on, and killings of, journalists in West Papua.

Support local initiatives through increased development aid funding that will strengthen capacities of local organisations, media outlets, and journalists in West Papua, while enabling greater transparency and credible documentation of the ongoing human rights crisis in West Papua.

\section{Conclusion}

The summary of the human rights abuses of journalists in West Papua presented in this article is evidence press freedom is a critical issue which needs to be addressed for the Indonesian government to be held accountable. Key violations have in the past occurred under the occupying Indonesian government in Timor-Leste. The deaths of the Balibo Five journalists raised international awareness of the plight of the East Timorese. The recommendations are a start to build global support to leverage change for the West Papuans. Importantly, these need to be actioned not only by the United Kingdom but also Australia.

\section{References}

Act of Free Choice (n.d.). Wikipedia. Retrieved from https://en.wikipedia.org/wiki/ Act_of_Free_Choice

AJI Jayapura: Wartawan Merauke tewas dibunah (2010, August 21). Antara News. Retrieved from https://www.antaranews.com/berita/217169/aji-jayapura-wartawanmerauke-tewas-dibunuh

Australian student barred from Indonesia and 'blacklisted' by government (2018, August 4). The Guardian. Retrieved from https://www.theguardian.com/world/2018/aug/04/ australian-student-barred-from-indonesia-and-blacklisted-by-government

Five Australian journalists expelled from Papua (2006, September 14). RSF (Reporters Without Borders). Retrieved from https://rsf.org/en/news/five-australian-journalistsexpelled-papua

Government keeps restrictive policy for foreign journalists covering in West Papua (2019, May 27). Human Rights and Peace for Papua: The International Coalition for Papua (ICP) of faith-based and civil society organisations. Retrieved from https:// www.humanrightspapua.org/news/31-2019/439-government-continues-restrictivepolicy-on-access-of-foreign-journalists-to-west-papua

Indonesia jails Polish tourist for treason (2019, May 2). BBC World News. Retrieved from https://www.bbc.co.uk/news/world-asia-48132165

Journalist killed as gunmen attack plane at Papua province airport (2012, April 11). RSP (Reporters Without Borders). Retrieved from https://rsf.org/en/news/journalist-killed- 
gunmen-attack-plane-papua-province-airport

Journalist's death overshadows launch of Papua food project (2010). Down to Earth. Retrieved from http://www.downtoearth-indonesia.org/story/journalist-s-deathovershadows-launch-papua-food-project

Kine, P. (2016, January 22). Indonesia's Papua reporting paranoia. Human Rights Watch. Retrieved from https:/www.hrw.org/news/2016/01/22/indonesias-papua-reportingparanoia

Kine, P. (2018, August 6). Indonesia's Papua media blacklist. Human Rights Watch. Retrieved from https://www.hrw.org/news/2018/08/06/indonesias-papua-mediablacklist-0

Media siluman di Papua: Propaganda, hoaks, hingga, narasumber fiktif(2018, December 6). Tirto. Retrieved from https://irto.id/media-siluman-di-papua-propaganda-hoakshingga-narasumber-fiktif-da5B

Papua-based reporter seriously injured in stabbing (2011, March 3). RSF (Reporters Without Borders). Retrieved from https://rsf.org/en/news/papua-based-reporterseriously-injured-stabbing

Polda Papua haras pecat pelaku kekerasan terhadap wartawan Jubi Abeth You dan Mando Mote di Nabire (2018, May 18). Suarapapua.com. Retrieved from https://suarapapua. com/2018/05/18/polda-papua-harus-pecat-pelaku-kekerasan-terhadap-wartawan-jubiabeth-you-dan-mando-mote-di-nabire/

RSF (Reporters Without Borders) (2019). RSF World Press Freedom Index: President's broken promises - Indonesia. Retrieved from https://rsf.org/en/indonesia

RSF asks Indonesia's president to let journalists work in West Papua (2017, March 31). RSF (Reporters Without Borders). Retrieved from https://rsf.org/en/news/rsf-asksindonesias-president-let-journalists-work-west-papua

RSF's [sic] decries journalist's expulsion from Indonesia's Papua region (2018, February 6). RSF (Reporters Without Borders). Retrieved from https://rsf.org/en/news/ rsfs-decries-journalists-expulsion-indonesias-papua-region

RSF tells Indonesia to stop flouting journalists' rights in West Papua (2016, May 9). RSF (Reporters Without Borders). Retrieved from https://rsf.org/en/news/rsf-tellsindonesia-stop-flouting-journalists-rights-west-papua

Sara, S., Worthington, A., \& Mambor, V. (2020, May 12). The battle for West Papuan independence from Indonesia has intensified with deadly results. ABC Foreign Correspondent. Retrieved from https://www.abc.net.au/news/2020-05-12/west-papuasecret-war-with-indonesia-for-independence/12227966 Also, Inside Indonesia's secret war for West Papua [Video]. Retrieved from https:/www.youtube.com/ watch? $\mathrm{v}=\mathrm{sMeYD}-\mathrm{wFC10}$

Setiawan, A. (2015, May 11). President Jokowi frees foreign journalists for journalistic duty to Papua. Cabinet Secretariat of the Republic of Indonesia. Retrieved from https://setkab.go.id/en/president-jokowi-frees-foreign-journalists-for-journalisticduty-to-papua/

Tehusijarana, K., \& Boediwardhana, W. (2018, December 4). Papuan students removed from Surabaya after rally. The Jakarta Post. Retrieved from https://www.thejakartapost.com/news/2018/12/04/223-papuan-students-removed-surabaya-after-rally.html

Two French journalists held for past five days in Indonesian province of Papua (2014, August 11) RSF (Reporters Without Borders). Retrieved from https://rsf.org/en/news/ two-french-journalists-held-past-five-days-indonesian-province-papua

UN Universal Periodic Review (2017). UPR Database. Retrieved from https://www. upr-info.org/database/index.php 
This article is drawn from a joint submission by the Indonesian human rights advocacy and research group TAPOL and the Tabloid Jubi newspaper of Jayapura, West Papua, in June 2019 to the inquiry by the Commons Select Committee into the Foreign and Commonwealth Office (FCO) and Global Media Freedom in an effort to combat disinformation. Pelagio da Costa Sarmento is a researcher for the London-based Indonesian human rights watchdog TAPOL. Victor Mambor is editor of the West Papuan news website Tabloid Jubi and a Jayapura correspondent of The Jakarta Post.

victor_mambor@tabloidjubi.com

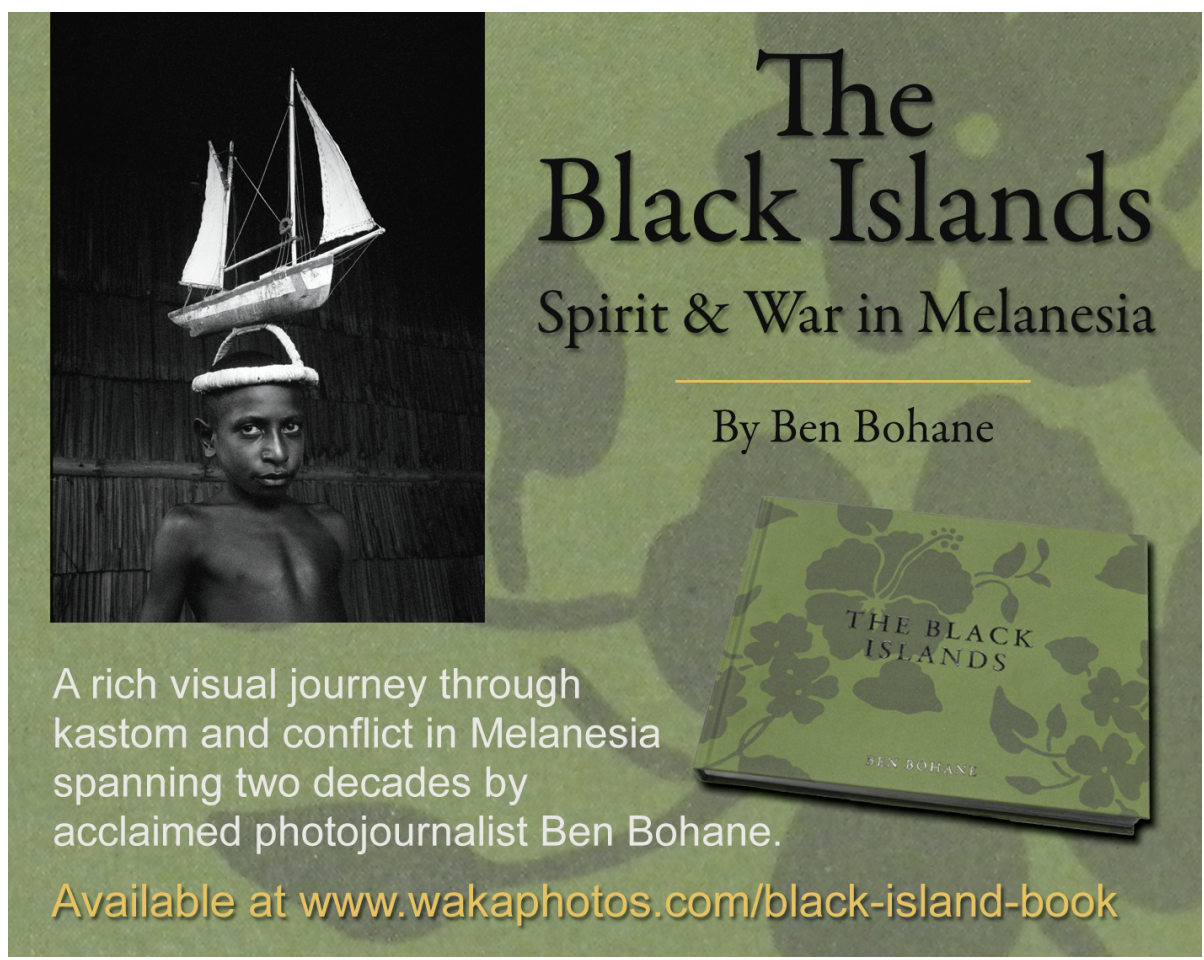

